\title{
Massive Open Online Course Related Learning Style and Technology Usage Patterns of Thai Tourism Professionals
}

\author{
https://doi.org/10.3991/ijet.v12.i11.7297 \\ Suepphong Chernbumroong( $\left.{ }^{\bowtie}\right)$, Pradorn Sureephong, Kitti Puritat \\ Chiang Mai University, Chiang Mai, Thailand \\ suepphongakic.camt.info
}

\begin{abstract}
The e-learning under the concept of massive open online courses (MOOCs) was adopted as an online learning system with the aim of promoting the Mutual Recognition Arrangement (MRA) of qualifications for ASEAN Tourism Professionals in Thailand.However, since the system has been implemented, the completion rate is very low compared to other MOOCs. For a better completion rate and learning outcome in MOOCs, the learning style and technology usage of user needs to be investigated.

The purpose of this research is to explore the learning styles of knowledge workers working as tourism professionals in five stars'hotels in Chiang Mai, Thailand. The total number of participants is 144 . Our research method was based on questionnaires consisted of two parts. The first part refers to the technology usage and the second part is the Index of Learning Styles (ILS) developed by Felder and Silverman (1988). Data were analyzed descriptively using the SPSS 20.0 for Windows. Results from the analysis showed that the smartphone is playing a dominant role which influences the technology usage of tourism professionals. The following learning styles could be identified as typical for the different learning dimensions: visual style for the input dimension; active style for the procession dimension; sequential style for the comprehension dimension and sensing style for the perception dimension. Based on the findings, the researchers suggest that the course designers and instructors of MOOCs should align their teaching approaches, strategies, methods and techniques with the dominant learning styles of each learning dimension.
\end{abstract}

Keywords-MOOCs, tourism professional, learning style, technology usage

\section{Introduction}

All the Association of Southeast Asian Nations (ASEAN) member countries, including Thailand will soon enter the ASEAN Economic Community (AEC) integration which will provide great opportunities to mobilize the knowledge workers of the tourism industry among its member countries, covering six divisions. The Mutual Recognition Arrangement (MRA) of qualifications of Tourism Professionals which is 
the framework of competency standards will be implementing and promoting the equality of human resources in the tourism industry [1]. According to the current situation, there are over two million tourism professionals in Thailand. However, tourism training facilities in Thailand are found to be poor in quality and the number of trainers is limited [2]. Therefore, online learning was adopted as a tool to re-skill the knowledge workers.

The e-learning platform under the concept of Massive Open Online Courses (MOOCs) was adopted as an online learning tool with the aim to provide and facilitate a channel of learning for the Thai tourism professionals, with the purpose to guarantee that they are well informed about the ASEAN - MRA competency standards in each position and able to have access to information anytime and anywhere. This elearning platform is also called "Thailand ACCSTP online learning system". However, this provided platform does not seem to facilitate or enhance the learning motivation and performance of learners. The completion rate of the Thai ACCSTP online learning system is only $0.9 \%$, which is very low compared to other MOOCs where the average rate of completion is less than 7\% [7]. For a better completion rate and learning outcome in MOOCs, the learning style and technology usage of the learners of the Thailand ACCSTP online learning system need to be investigated.

The learning style can be defined as the preferred way on which an individual receives, maintains and facilitates the understanding of obtained information [3]. Many studies reported that when instructors deliver course learning materials which match with the preferences of the learners, learning is enhanced and the course performance improves [40]. In contrast, a mismatch between the teaching style and the learning style could provide a negative effect in academic performance among the learners. Since the research on technology usage and learning style in the tourism domain in Thailand is very seldom, the aim of this research is to identify the pattern of technology usage and learning styles among the knowledge workers who are working as tourism professionals in five star hotels in Chiang Mai, Thailand, covering six divisions.

\section{Background and Statement of Problem}

The ASEAN Economic Community (AEC) will soon be established and this scenario will provide a good opportunity for the knowledge workers in the tourism industry, since the certified qualifications and certified tourism professional standards will allow them to travel and work in all the ASEAN member countries. Therefore, the member countries have prepared the ASEAN Common Competency Standards for Tourism Professionals (ACCSTP) which aims to promote the equality of human resources in the tourism industry and to facilitate the mobility of tourism professionals [1]. Furthermore, the framework is mainly providing standard performances for tourism professionals. There are 6 divisions ( 32 job titles) covered by this standard, ranging from housekeeping, front office, food and beverages services, food production for the hotel division, to travel agencies and tour operators for the travel division. The knowledge worker in each position who would like to achieve the tourism professional personnel standards of ASEAN needs to obtain the ASEAN - MRA competencies 
as follows: Common Core Competencies, Generic Competencies and Functional Competencies (total 242 competencies) [1]. Since there are over two million tourism professionals in Thailand, many projects were developed as part of a strategy to reskill and facilitate the knowledge to perform actively. Recently, the government of Thailand has put an emphasis on generating a platform to disseminate the content of tourism standards and to improve their tourism workers' skills. However, there have been reports showing gaps between the MRA requirements and the implementation of MRA projects in Thailand.

The gaps are considered to be important problems that the Thai government needs to overcome in order to improve the knowledge workers in the tourism industry. For example, the tourism training facilities in Thailand are found to be poor in quality with low standards of construction and have not taking care of. Appropriately equipped training facilities are important for the effective delivery of competencybased vocational education and training for the tourism workers. A typical problem behind this example is the lack of available funds. Another example is attracting and retaining of suitable tourism trainers. It should be noted that only trainers who are skilful and passionate about their vocations are suitable for the role of delivering vocational trainings to others. From this point of view, the one who turns to be a professional has the most probability to take middle level management roles and to enjoy high levels of benefits and remuneration from the positions. Therefore, the number of trainers who are disseminating the content is very low [2]. Furthermore, the characteristics of the knowledge workers in the tourism industry do not correspond with the learning platform. The statistics from Chula Unisearch has shown that the average working day per week of a Thai tourism worker is 6 days and the average working time per day is 9 hours [6]. As mentioned, the learning platforms like lecture classes or workshop-based learning might not match with their working styles because the workers have a fixed time to spend in the classroom.

Fortunately, the e-learning platform under the concept of Massive Open Online Course (MOOC) was adopted as an online learning concept with the aim to facilitate and provide a channel for the Thai tourism professionals to learn and make them well informed about the ASEAN - MRA competency standards in each position with an easy access anytime and anywhere [28]. This e-learning platform is also called "Thailand ACCSTP online learning system". However, the provided MOOC platforms don't seem to facilitate or enhance the learning motivation and performance of users. The table below presents the statistics of users of Thai ACCSTP online learning system for the last 2 years. The rate of registration is $100 \%$ while the rate of users who enrolled the online course is $32.6 \%$. Only $8.2 \%$ of the users were asked for online examination and $0.9 \%$ of the users achieved the test and completed the course (completion rate refers to users who actually obtained the certificate at the end of course).

Table 1. Rate of the Thai ACCSTP online learning system usage.

\begin{tabular}{|c|c|c|c|}
\hline Registration & Enrollment & Examination & Completion \\
\hline $100 \%$ & $32.6 \%$ & $8.2 \%$ & $0.9 \%$ \\
\hline
\end{tabular}


As mentioned, the completion rate of the Thai ACCSTP online learning system is only $0.9 \%$ which is very low compared to other MOOCs where the average rate of completion is less than 7\% [7]. The completion rate of MOOCs is considered to be significant issues since the statistics of users of other popular MOOCs have shown that many online learners lose their interest after a few weeks of course [27]. Therefore, this research aimed to investigate the knowledge workers' learning styles as well as the technology usage of such tourism professionals.

\section{Research objectives}

1. To identify the usage of technology devices such as smartphones, tablets and PCs of tourism professionals as knowledge workers.

2. To identify the pattern of learning styles among tourism professional.

3. To identify differences among tourism professional.

\section{Literature review}

\subsection{Massive Open Online Learning}

Recently, Massive Open Online Courses (MOOCs) have received worldwide attention representing a new model of delivery of online learning to students. Many academic institutions have invested considerable effort in developing, promoting and delivering their courses. Therefore, the number of MOOC registrations has grown dramatically [23]. One of the reasons behind this success can be that MOOC is able to solve many educational problems. For example, the participation in MOOCs is free and easily accessible via internet. Moreover, all the content is open for the participants and they might take more than one course. Furthermore, learners in remote areas and even in developing countries are having access to the content via internet [37].

The concept of MOOC is not entirely new since it first appeared one decade ago as "connectivist" or "cMOOCs" which was mainly based on peer and social learning model [34]. Later on "XMOOCs" emerged, with the " $X$ " coming from the name of MOOC providers MITx and edX. "xMOOC" emphasized the potential of accessing materials and instructors of world-class universities such as Stanford, Harvard and MIT [31]. These xMOOCs learning-management models were based on online courses including video-based lectures, assessment and messaging. Learners can access relevant sources of information in their own space. Moreover, there are activities in MOOCs such as automated multiple choice quizzes, short videos, document sharing and forums.

As regards MOOCs as online learning platforms provided by the Thai government, many learning features are implemented in the courses. Below is a detailed list of MOOCs features which are appeared in Thailand ACCSTP online learning systems; 
- Video lecture: generally video lectures in MOOCs have many presentation styles. In our system, the video lectures' length is typically not more than 6-7 minutes since it is the appropriate length for our user [33].

- Interactive serious games: serious games have the ability to meet user expectation by providing a feedback in the form of interaction data that can be used for detailed analytics [26]. Furthermore, interactive games also improve the learning performance of users in an online learning environment [33].

- Reading: journals and textbooks relevant to our courses are available online and provided by the course instructors.

- Activities: plenty of instructor activities are offered such as automated quizzes allowing learners to further test their understanding on the course concepts.

The above described features of MOOCs are implemented with the aim of enhancing user engagement in the online learning environment and to encourage all Thai tourism workers to meet the ACCSTP standards. However, it has been unclear why leaners choose MOOCs and the reasons behind such decisions. Furthermore, it has been noted that the completion rate in this kind of MOOC is less than $7 \%$ in average [7]. Thus, a better understanding on learner usage and behaviour regarding MOOCs could lead to better results.

Since relatively little is known about why learners choose MOOCs, Kizilcec and his colleagues [21] suggested that for a better understanding of MOOC learners, the learner usage of MOOCs needs to be investigated. Thus, there have been many scholars trying to investigate the nature of learner usage of MOOCs in order to design the appropriate features in MOOCs for them. For example, Guo, Kim, and Rubin (2014) [18] examined video watching data from 6.9 million video watching sessions and proposed that shorter videos, inclusion of instructor talking-head videos and presence of drawing-hand style instructions led to better engagement. Coetzee et al. (2014) [8] conducted their research to investigate learner activities within discussion forums by examining whether the presence of a forum reputation feature can influence student performance. Their result showed that the presence of the forum reputation correlated with higher course retention. In another interesting experiment, the cognitive load theory was employed to improve the knowledge workers' learning performance in MOOCs via mobile devices [33]. The results indicated that learners who were using smaller length video lectures performed significantly better than those with the longer video length. Furthermore, the groups of knowledge workers who were equipped with interactive media achieved higher test scores than those in non-interactive groups. The last example is based on the data collection of [18], whose results showed that the pattern of learner navigation among multiple key MOOC components including discussion forums, videos, wikis, etc. is non-linear.

Most of the above mentioned MOOC studies focused on learner such as video watching habits and navigation patterns. Existing researches tend to adopt a limited view of learning behaviour that does not acknowledge the complexity and dynamic interplay of factors underlying and influencing motivation of learning. Therefore, investigation on learning styles could provide a better understanding of the learners. 
Paper-Massive Open Online Course Related Learning Style and Technology Usage Patterns of Thai...

\subsection{Learning Style}

Learning style can be defined as the preferred way on which an individual receives, maintains and facilitates the understanding of obtained information [3]. Generally, different learners have different ways to perceive, process, remember and recall information. For instance, some learners might like to learn by seeing, hearing, responding, giving logical reasoning, or by remembering and learning by using graphics [5]. In addition, the learning style preferences also influence the learning performance. With preferred learning styles, learners can better perceive and process the information [10]. Leaners with a learning style preference matching the instructor's teaching style seem to retain information longer [11] and are able to apply knowledge more effectively compared to learners who has a mismatch with the instructor's teaching style [12]. Moreover, they could also comprehend the lesson, complete tasks and do classroom activities more easily [30]. According to the above scope and the benefits of learning styles, many researchers tried to understand the learners' learning styles in order to design and develop the appropriate teaching technique and to create a guideline for other instructors.

Previously, many researchers have conducted their studies based on learning style evaluation models [10]. Different learning style models have been developed to assess learning style preferences in different contexts and with different focuses. Plenty of learning style models have been developed by applying different psychological theories and appeared in some previous studies such as the Myers-Briggs Type Indicator (MBTI); the Grasha Reichmann Learning Style Scale (GRLSS); the Learning Style Inventory (LSI); the Visual, Aural, Read/Write, and Kinesthetic learning styles (VARK); and the Index of Learning Styles (ILS). As mentioned, these different models have adopted different criteria for the classification of learning style preferences (see Table 2).

According to the different models of learning styles presented in Table 2, this study employed the Index of Learning Styles or ILS developed by Felder and Soloman (1991) [13] as the basis for the study. The justification for employing the ILS model is that it was found to cover the widest scope of learning style dimensions (see table 2) compared to other learning style models (MBTI, GRLSS, LSI and VARK). Furthermore, the ILS had been used in a number of previous research studies [15] [16] [17] [19] [20] and its reliability has been examined [25]. 
Table 2. The comparison of different learning style models.

\begin{tabular}{|c|c|c|c|c|}
\hline Model & Developer & $\begin{array}{l}\text { Criteria for classifica- } \\
\text { tion of learning styles }\end{array}$ & $\begin{array}{c}\text { Dimensions of learning } \\
\text { styles }\end{array}$ & Instrument \\
\hline $\begin{array}{l}\text { Myers-Briggs } \\
\text { Type Indicator } \\
\text { (MBTI) }\end{array}$ & $\begin{array}{l}\text { Isabel Briggs } \\
\text { Myers (1940) }\end{array}$ & $\begin{array}{l}\text { Personality-related } \\
\text { preferences }\end{array}$ & $\begin{array}{l}\text { Extraverts/intro verts } \\
\text { Sensors/intuitions } \\
\text { Thinkers/feelers Judg- } \\
\text { ers/perceivers }\end{array}$ & $\begin{array}{l}\text { Myers-Briggs } \\
\text { Type Indicator } \\
(93 \text { forced choice } \\
\text { items })\end{array}$ \\
\hline $\begin{array}{l}\text { GrashaReich- } \\
\text { mann Learning } \\
\text { Style Scale } \\
\text { (GRLSS) }\end{array}$ & $\begin{array}{l}\text { Anthony Grasha } \\
\text { and Sheryl } \\
\text { HruskaReich- } \\
\text { mann (1974) }\end{array}$ & Interaction Preferences & $\begin{array}{l}\text { Avoidance Participation } \\
\text { Competitiveness Collabo- } \\
\text { ration Dependence Inde- } \\
\text { pendence }\end{array}$ & $\begin{array}{l}\text { Grasha Reich- } \\
\text { mann Learning } \\
\text { Style Scale ( } 60 \\
\text { items rated on a } \\
\text { Likert scale) }\end{array}$ \\
\hline $\begin{array}{l}\text { Learning Style } \\
\text { Inventory (LSI) }\end{array}$ & $\begin{array}{l}\text { David Kolb } \\
\text { (1984) }\end{array}$ & $\begin{array}{l}\text { Information } \\
\text { Processing } \\
\text { Preference }\end{array}$ & $\begin{array}{l}\text { Diverging learners Assimi- } \\
\text { lating Learners Converging } \\
\text { Learners Accommodating } \\
\text { learners }\end{array}$ & $\begin{array}{l}\text { Learning Style } \\
\text { Inventory ( } 12 \\
\text { items rated on a } \\
\text { Likert scale) }\end{array}$ \\
\hline $\begin{array}{l}\text { Visual, Aural, } \\
\text { Read/Write, and } \\
\text { Kinesthetic } \\
\text { Learning Styles } \\
\text { (VARK) }\end{array}$ & $\begin{array}{l}\text { Neil Fleming } \\
(1987)\end{array}$ & $\begin{array}{l}\text { Sensory } \\
\text { Learning } \\
\text { Preference }\end{array}$ & $\begin{array}{l}\text { Visual Aural Read/Write } \\
\text { Kinesthetic }\end{array}$ & $\begin{array}{l}\text { Visual, Auditory, } \\
\text { Read/Write. and } \\
\text { Kinesthetic } \\
\text { Learning Styles } \\
\text { (13 multiple } \\
\text { choice items) }\end{array}$ \\
\hline $\begin{array}{l}\text { Index of Learn- } \\
\text { ing Styles (ILS) }\end{array}$ & $\begin{array}{l}\text { Richard Felder } \\
\text { and Barbara } \\
\text { Soloman (1991) }\end{array}$ & $\begin{array}{l}\text { Information } \\
\text { Processing } \\
\text { Preference }\end{array}$ & $\begin{array}{l}\text { Sensory/intuitive learners } \\
\text { Visual/verbal learners } \\
\text { Active/ } \\
\text { Reflective learners Sequen- } \\
\text { tial/global learners }\end{array}$ & $\begin{array}{l}\text { Index of Learning } \\
\text { Styles ( } 44 \text { multi- } \\
\text { ple choice items) }\end{array}$ \\
\hline
\end{tabular}

\subsection{Index of Learning Styles}

The Index of Learning Styles (ILS) was developed by Richard Felder and Barbara Solomon of North Carolina State University. ILS is also a self-scoring web-based instrument which was placed on the World Wide Web in 1996. There is no cost for ILS access and it is available for all individuals who want to evaluate their own learning style or to any instructors and learners who wants to use it for classroom teaching or research, and it can be licensed by non-educational organizations [10]. Moreover, the instrument is user friendly and the results are easy to interpret.

Generally, the ILS instrument was divided into four dimensions of learning styles where each dimension comprised of two sub-scales such as the dimension of Procession (Active / Reflective learners), Perception (Sensing / Intuitive learners), Input (Visual / Verbal learners) and Comprehension (Sequential / Global learners). According to the ILS instrument, each dimension of the learning styles is associated with 11 forced-choice items (forced choice), with each option ('a' or 'b') corresponding to each dimension separately. The respondents are asked to select one of the provided answers. 


\section{Perception}

- Sensing learner - they feel comfortable perceiving information through the five physical senses. In addition, they are good at memorizing facts. They are careful but may be sometimes slow. Their information preference is facts, concrete data and experiments [29].

- Intuitive learner - they use their memories and thoughts in learning. Normally, they are good at grasping new concepts. They are quick but may be careless. Their information preference is principles, concepts and theories [29].

\section{Input}

- Visual leaner - they remember best what they see: information in pictures. They also prefer teachers who are using teaching aids and the use of graphics. Their information preference is photographs, drawings, diagrams, series, films and demonstrations [4].

- Verbal learner - they are students who love learning through words. They remember best when they hear something and more of what they hear and then say. Thus, verbal learners learn effectively by explaining things to others. Their information preference is sound, auditory inputs, word, text and explanation [4].

\section{Procession}

- Active learner - they feel more comfortable with active experimentation and they also work well in groups. Their information preference is discussing, brain storming, experimenting and testing [22].

- Reflective leaner - they prefer to learn through thinking or working independently. Furthermore, they prefer to observe and think about the information silently. Thus, their attribute is thinking, observation and independent learning [22].

\section{Comprehension}

- Sequential learner - they usually follow linear reasoning processes when solving problems. Therefore, they are strong in convergent thinking and analysis. Their information preference is a systematic, structured manner or a step by step approach [35].

- Global learner - they are students who are keen to gather information in order to understand something. They are better at divergent thinking and synthesis. Their information preference is a combination of various pieces of information fitting together into the big picture [35].

\section{$4 \quad$ Research Methodology}

In our research, a quantitative method was employed. Creswell explains the characteristics of the quantitative method: "it involves a numeric description of trends, 
attitudes, or opinions of a population by studying a participant of that population" [9]. Therefore, the quantitative method was appropriate for the study since our research is based on gathering data on a large scale to identify the trends and overall learning style preferences of the knowledge workers in the tourism industry.

\subsection{Participants}

The participant selection in our research was employed using purposive sampling as the sampling method. Purposive sampling is the selection of research participants based on the qualifications that the researcher wants to explore [24]. The sample in this study contains knowledge workers of the tourism industry who are working in five star hotels in Chiang Mai, Thailand, covering six divisions. The total number of participants was 144. The mean age was 31 - 40 years and there were 92 women and 52 men. As regards the levels of education, $51.4 \%$ of the participants held a bachelor degree, $23.6 \%$ held a master degree and $22.3 \%$ were undergraduate. As regards the various divisions, 30 participants were from housekeeping, 34 were from front office, 14 were from food and beverages services, 22 were from food production, 20 were from travel agencies, 18 were from tour operation and 6 were from other divisions such as information technology (IT) and human resources (HR).

\subsection{Instrument}

In our research, a set of questionnaire was used as the instrument for collecting data. The questionnaire technique was employed since the administration procedures are simple and easy to control. Furthermore, the questionnaire is also able to help and facilitate the participants on answering the items. With a simple task, the participant will be more responsible and cooperative [36]. The set of questionnaire was divided into 2 parts; the first part refers to the technology usage and the second part refers to the Index of Learning Style. The first part of the survey questionnaire aims to collect the data of technology usage based on three devices; personal computer, smart phone and tablet. All questions were in Thai and were short multiple choice questions (Table 3).

The questionnaire set of the second part was adopted from the Felder Silverman ILS [13]. The Index of Learning Styles (ILS) is a questionnaire developed for assessing learners' learning style preferences by Richard Felder and Barbara Soloman in 1991. The ILS questionnaire consists of 44 questions to assess the four dimensions of the learning style model including sensory or intuitive, visual or verbal, active or reflective, and sequential or global learning styles (see table 4). Moreover, each item in the ILS is related to one dimension of the learning styles, each of them divided into two alternative types of learning styles for the participants to choose from. 
Table 3. Technology usage survey questionnaire

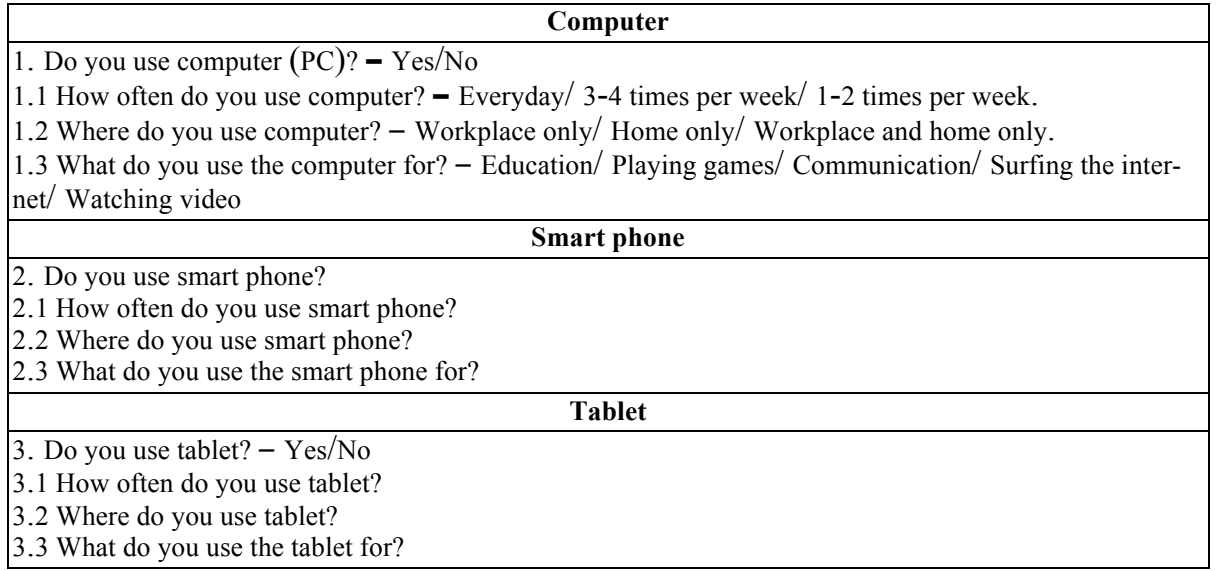

Table 4. Breakdown of 4 dimensions and 4 sub-scales of the Felder \& Silverman learning styles.

\begin{tabular}{|l|c|}
\hline \multicolumn{1}{|c|}{ Dimension and sub-scales } & Items \\
\hline Processing (Active / Reflective) & $25,1,29,5,17,37,13,9,21,33,41$ \\
\hline Perception (Sequential / Intuitive) & $38,6,18,14,2,10,34,26,22,42,30$ \\
\hline Input (Visual / Verbal) & $7,31,23,11,15,27,19,3,35,43,39$ \\
\hline Comprehension (Sequential / Global) & $20,36,44,8,12,32,34,28,4,16,40$ \\
\hline
\end{tabular}

The main reason why ILS was applied is that participants are able to selfadminister this questionnaire at no cost. Furthermore, the four learning style dimensions are numerically coded and could be easily quantified for the analysis. In addition, the ILS has been validated [14]. The original ILS questionnaire was translated from English to Thai which aims to help the participants clearly understand all the questions.

\subsection{Data Analysis}

According to the Index of Learning Styles, each dimension of the learning styles is associated with 11 forced-choice items (forced choice or selected response), with each option ( $a$ or $b$ ) corresponding to each dimension separately. It is convenient to use a scoring method that counts ' $a$ ' responses, so that a score on a dimension would be an integer ranging from 0 to 11 . Using the active-reflective dimension as an example (see table 5), the respondents were asked to select one of the provided answers.

Part 1: Results and analysis. Figure 1 demonstrates the overall technology usage of three different devices among 144 tourism professionals who are working in five star hotels in Chiang Mai. Smartphones are the most commonly used device with $95.8 \%$, closely followed by PCs with $88.9 \%$. Tablets are the least used device with only $43.1 \%$. 
Table 5. An example of data analysis on the active-reflective dimension.

\begin{tabular}{|l|c|}
\hline \multicolumn{1}{|c|}{ dimension } & "A" respond \\
\hline Strongly Active & $10-11$ \\
\hline Moderately Active & $8-9$ \\
\hline Mildly Active & $6-7$ \\
\hline Mildly Reflective & $4-5$ \\
\hline Moderately Reflective & $2-3$ \\
\hline Strongly Reflective & $0-1$ \\
\hline
\end{tabular}

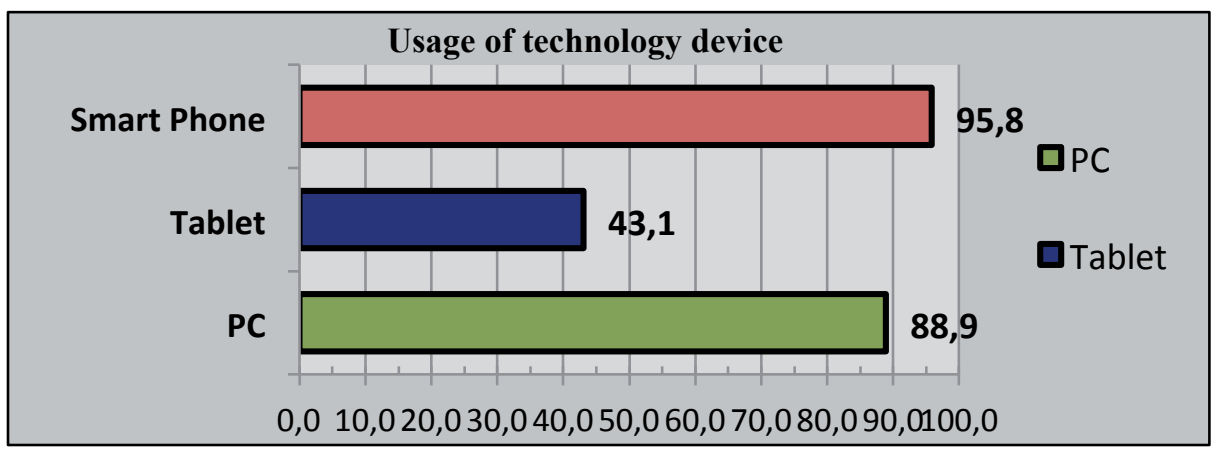

Fig. 1. Overall usage of technology services.

Table 6 presents the information on usage frequency and usage location of technology devices. The result showed that most of our participants use smart phones almost every day with $97 \%$, whereas only $1.4 \%$ of the participants use their smart phone 1-4 times per week. As regards tablet (77.4\%) and PC (75\%), the participants use these devices almost every day. The average time of device usage for smart phones is $4-6$ hours per day $(49.3 \%)$, whereas tablet is used $1-3$ hours per day by $61.3 \%$ and PC is used $1-3$ hours per day by $42.2 \%$ of the respondents. Furthermore, the information on location showed that all of our participants prefer to use their devices both at their workplace and at home (smart phone $94 \%$, tablet $71 \%$, and PC $62.5 \%)$.

Figure 2 demonstrates the purpose of technology usage in five different domains. Browsing the internet is the most common purpose for PC usage (98.4\%) and tablet usage $(100 \%)$, whereas the most common purpose for smart phones is communication (97.1\%). Over $80 \%$ of the participants use all the three different devices for educational purposes, while playing game is the least common purpose for device usage.

\subsection{Discussion and recommendations}

Taking a look at the current landscape of technology usage among knowledge workers in the tourism industry and it is clearly visible that smartphones play a dominant role. The above information has reported that the smartphone usage is higher than the usage of any other devices. However, the smartphone was very closely fol- 
Table 6. Frequency and location of technology usage

\begin{tabular}{|l|c|c|c|c|c|c|c|c|c|}
\hline \multirow{2}{*}{ Device } & \multicolumn{3}{|c|}{ Per week (\%) } & \multicolumn{3}{c|}{ Per day (\%) } & \multicolumn{3}{c|}{ Location (\%) } \\
\cline { 2 - 10 } & Everyday & $\begin{array}{c}\mathbf{3 - 4} \\
\text { time }\end{array}$ & $\begin{array}{c}\mathbf{1 - 2} \\
\text { time }\end{array}$ & $\begin{array}{c}\text { Over7 } \\
\text { hours }\end{array}$ & $\begin{array}{c}\mathbf{4 - 6} \\
\text { hours }\end{array}$ & $\mathbf{1 - 3}$ hours & Workplace & $\begin{array}{c}\text { Hom } \\
\boldsymbol{e}\end{array}$ & $\begin{array}{c}\text { Workplace } \\
\text { and home }\end{array}$ \\
\hline Smart phone & 97.1 & 1.4 & 1.4 & 33.3 & 49.3 & 17.4 & 1.4 & 4.3 & 94.2 \\
\hline Tablet & 77.4 & 9.7 & 12.9 & 6.5 & 32.3 & 61.3 & 0 & 29 & 71 \\
\hline PC & 75 & 9.4 & 15.6 & 23.4 & 34.4 & 42.2 & 10.9 & 26.6 & 62.5 \\
\hline
\end{tabular}

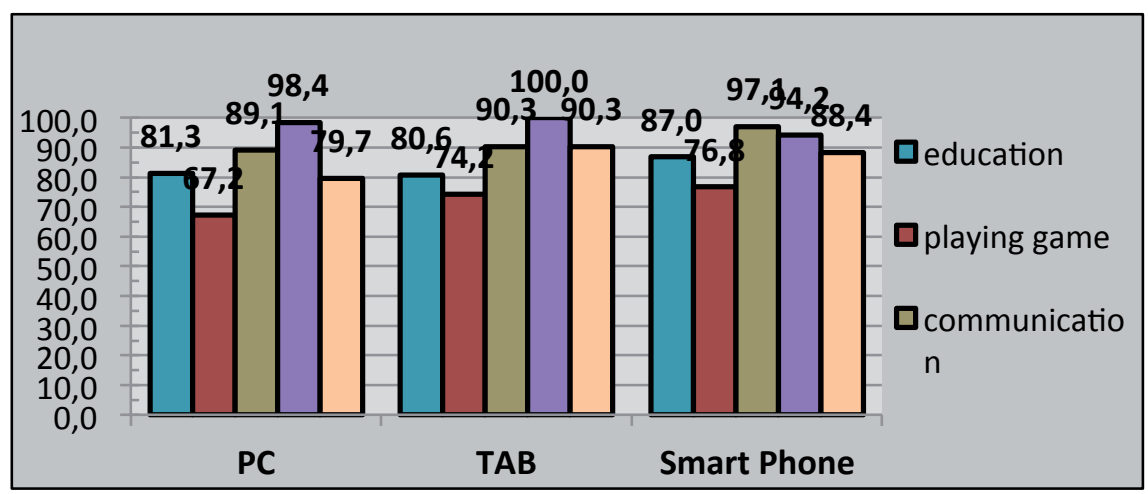

Fig. 2. The purpose of technology usage.

lowed by the PC in terms of usage frequency. Also it can be noted that smartphones were mostly used for communication and PCs were mostly used for browsing the internet. Hence, mobile technology is not necessarily replacing the PC but it could be offering new types of user experience. On the other hand, the frequency of tablet usage turned out to be the lowest among all devices, which is not surprising given the fact that it is also the newest device category in online learning. Tablets are commonly used at the workplace and at home, and the most popular purpose of usage is browsing the internet. However, it can be noted that tablets are the most frequently used devices for watching videos, more respondents use these devices to watch videos than PCs or smartphones. Hence, it seems to be possible to adapt this movie-watching capacity of tablets on the domain of education in the future.

Part 2: Results and analysis. Table 7 presents the distribution of learning styles among the 144 knowledge workers who are working as tourism professionals in five star hotels in Chiang Mai, Thailand, covering six divisions. The participants are more visual than verbal as regards input preferences (61.2\% and $38.8 \%$ respectively); they are more active than reflective as regards the dimension of procession $(77.8 \%$ and $22.2 \%$ respectively); their style of comprehension is more sequential than global ( $83.4 \%$ and $16.6 \%$ respectively); and as regards their style of perception they are more sensing than intuitive $(88.9 \%$ and $11.1 \%$ respectively). 
Paper-Massive Open Online Course Related Learning Style and Technology Usage Patterns of Thai...

Table 7. Overall distribution of the learning style dimensions for tourism professionals in six divisions.

\begin{tabular}{|c|c|c|c|c|c|}
\hline \multicolumn{6}{|c|}{ Procession } \\
\hline & & Frequency & Percent & Valid Percent & $\begin{array}{c}\text { Cumulative } \\
\text { Percent }\end{array}$ \\
\hline \multirow{3}{*}{ Valid } & Active & 112 & 77.8 & 77.8 & 77.8 \\
\hline & Reflective & 22 & 22.2 & 22.2 & 100.0 \\
\hline & Total & 144 & 100.0 & 100.0 & \\
\hline \multicolumn{6}{|c|}{ Perception } \\
\hline & & Frequency & Percent & Valid Percent & $\begin{array}{c}\text { Cumulative } \\
\text { Percent }\end{array}$ \\
\hline \multirow{3}{*}{ Valid } & Sensing & 128 & 88.9 & 88.9 & 88.9 \\
\hline & Intuitive & 16 & 11.1 & 11.1 & 100.0 \\
\hline & Total & 144 & 100.0 & 100.0 & \\
\hline \multicolumn{6}{|c|}{ Input } \\
\hline & & Frequency & Percent & Valid Percent & $\begin{array}{c}\text { Cumulative } \\
\text { Percent }\end{array}$ \\
\hline \multirow{3}{*}{ Valid } & Visual & 88 & 61.2 & 61.2 & 61.2 \\
\hline & Verbal & 56 & 38.8 & 38.8 & 100.0 \\
\hline & Total & 144 & 100.0 & 100.0 & \\
\hline \multicolumn{6}{|c|}{ Comprehension } \\
\hline & & Frequenoy & Percent & Valid Percent & $\begin{array}{c}\text { Cumulative } \\
\text { Percent }\end{array}$ \\
\hline \multirow{3}{*}{ Valid } & Sequent & 120 & 83.4 & 83.4 & 83.4 \\
\hline & Global & 24 & 16.6 & 16.6 & 100.0 \\
\hline & Total & 144 & 100.0 & 100.0 & \\
\hline
\end{tabular}

Table 8 presents the distribution of learning styles of 30 knowledge workers who are representing the housekeeping division. The participants are more verbal than visual as regards input preferences (53.3\% and $46.7 \%$ respectively); they are more active than reflective as regards the dimension of procession $(86.7 \%$ and $13.3 \%$ respectively); their style of comprehension is more sequential than global $(60 \%$ and $40 \%$ respectively); and as regards their style of perception they are more sensing than intuitive ( $80 \%$ and $20 \%$ respectively). 
Paper-Massive Open Online Course Related Learning Style and Technology Usage Patterns of Thai...

Table 8. Overall distribution of the learning style dimension in housekeeping division.

\begin{tabular}{|c|c|c|c|c|c|}
\hline \multicolumn{6}{|c|}{ Procession } \\
\hline & & Frequency & Percent & Valid Percent & $\begin{array}{c}\text { Cumulative } \\
\text { Percent }\end{array}$ \\
\hline \multirow{3}{*}{ Valid } & Active & 26 & 86.7 & 86.7 & 86.7 \\
\hline & Reflective & 4 & 13.3 & 13.3 & 100.0 \\
\hline & Total & 30 & 100.0 & 100.0 & \\
\hline \multicolumn{6}{|c|}{ Perception } \\
\hline & & Frequency & Percent & Valid Percent & $\begin{array}{c}\text { Cumulative } \\
\text { Percent }\end{array}$ \\
\hline \multirow{3}{*}{ Valid } & Sensing & 24 & 80.0 & 80.0 & 80.0 \\
\hline & Intuitive & 6 & 20.0 & 20.0 & 100.0 \\
\hline & Total & 30 & 100.0 & 100.0 & \\
\hline \multicolumn{6}{|c|}{ Input } \\
\hline & & Frequenoy & Percent & Valid Percent & $\begin{array}{c}\text { Cumulative } \\
\text { Percent }\end{array}$ \\
\hline \multirow{3}{*}{ Valid } & Visual & 14 & 46.7 & 46.7 & 46.7 \\
\hline & Verbal & 16 & 53.3 & 53.3 & 100.0 \\
\hline & Total & 30 & 100.0 & 100.0 & \\
\hline \multicolumn{6}{|c|}{ Comprehension } \\
\hline & & Frequenoy & Percent & Valid Percent & $\begin{array}{c}\text { Cumulative } \\
\text { Percent }\end{array}$ \\
\hline \multirow{3}{*}{ Valid } & Sequent & 18 & 60.0 & 60.0 & 60.0 \\
\hline & Global & 12 & 40.0 & 40.0 & 100.0 \\
\hline & Total & 30 & 100.0 & 100.0 & \\
\hline
\end{tabular}

Table 9 presents the distribution of the learning styles of 34 knowledge workers from the front office division. The participants are more visual than verbal as regards input preferences $(64.7 \%$ and $35.3 \%$ respectively); they are more active than reflective as regards the dimension of procession ( $70.6 \%$ and $29.4 \%$ respectively); their style of comprehension is more sequential than global $(76.5 \%$ and $23.5 \%$ respectively); and as regards their style of perception they are more sensing than intuitive $(94.1 \%$ and $5.9 \%$ respectively). 
Paper-Massive Open Online Course Related Learning Style and Technology Usage Patterns of Thai...

Table 9. Overall distribution of the learning style dimensions in the front office division.

\begin{tabular}{|c|c|c|c|c|c|}
\hline \multicolumn{6}{|c|}{ Procession } \\
\hline & & Frequency & Percent & Valid Percent & $\begin{array}{c}\text { Cumulative } \\
\text { Percent }\end{array}$ \\
\hline \multirow{3}{*}{ Valid } & Active & 24 & 70.6 & 70.6 & 70.6 \\
\hline & Reflective & 10 & 29.4 & 29.4 & 100.0 \\
\hline & Total & 34 & 100.0 & 100.0 & \\
\hline \multicolumn{6}{|c|}{ Perception } \\
\hline & & Frequency & Percent & Valid Percent & $\begin{array}{c}\text { Cumulative } \\
\text { Percent }\end{array}$ \\
\hline \multirow{3}{*}{ Valid } & Sensing & 32 & 94.1 & 94.1 & 94.1 \\
\hline & Intuitive & 2 & 5.8 & 5.9 & 100.0 \\
\hline & Total & 34 & 100.0 & 100.0 & \\
\hline \multicolumn{6}{|c|}{ Input } \\
\hline & & Frequency & Percent & Valid Percent & $\begin{array}{c}\text { Cumulative } \\
\text { Percent }\end{array}$ \\
\hline \multirow{3}{*}{ Valid } & Visual & 22 & 64.7 & 64.7 & 64.7 \\
\hline & Verbal & 12 & 35.3 & 35.3 & 100.0 \\
\hline & Total & 34 & 100.0 & 100.0 & \\
\hline \multicolumn{6}{|c|}{ Comprehension } \\
\hline & & Frequency & Percent & Valid Percent & $\begin{array}{c}\text { Cumulative } \\
\text { Percent }\end{array}$ \\
\hline \multirow{3}{*}{ Valid } & Sequent & 26 & 76.5 & 76.5 & 76.5 \\
\hline & Global & 8 & 23.5 & 23.5 & 100.0 \\
\hline & Total & 34 & 100.0 & 100.0 & \\
\hline
\end{tabular}

Table 10 presents the distribution of the learning styles of 14 knowledge worker who are working at the food and beverages services division. The participants are more visual than verbal as regards input preferences ( $85.7 \%$ and $14.3 \%$ respectively); they are more active than reflective as regards the dimension of procession $(100 \%$ and $0 \%$ respectively); their style of comprehension is more sequential than global $(100 \%$ and $0 \%$ respectively); and as regards their style of perception they are more sensing than intuitive ( $85.7 \%$ and $14.3 \%$ respectively). 
Paper-Massive Open Online Course Related Learning Style and Technology Usage Patterns of Thai...

Table 10. Overall distribution of the learning style dimensions in the food and beverages services division.

\begin{tabular}{|c|c|c|c|c|c|}
\hline \multicolumn{6}{|c|}{ Procession } \\
\hline & & Frequency & Percent & Valid Percent & $\begin{array}{c}\text { Cumulative } \\
\text { Percent }\end{array}$ \\
\hline \multirow{3}{*}{ Valid } & Active & 14 & 100.0 & 100.0 & 100.0 \\
\hline & Reflective & 0 & 0 & 0 & \\
\hline & Total & 14 & 100.0 & 100.0 & \\
\hline \multicolumn{6}{|c|}{ Perception } \\
\hline & & Frequency & Percent & Valid Percent & $\begin{array}{c}\text { Cumulative } \\
\text { Percent }\end{array}$ \\
\hline \multirow{3}{*}{ Valid } & Sensing & 12 & 85.7 & 85.7 & 85.7 \\
\hline & Intuitive & 2 & 14.3 & 14.3 & 100.0 \\
\hline & Total & 14 & 100.0 & 100.0 & \\
\hline \multicolumn{6}{|c|}{ Input } \\
\hline & & Frequency & Percent & Valid Percent & $\begin{array}{c}\text { Cumulative } \\
\text { Percent }\end{array}$ \\
\hline \multirow{3}{*}{ Valid } & Visual & 12 & 85.7 & 85.7 & 85.7 \\
\hline & Verbal & 2 & 14.3 & 14.3 & 100.0 \\
\hline & Total & 14 & 100.0 & 100.0 & \\
\hline \multicolumn{6}{|c|}{ Comprehension } \\
\hline & & Frequenoy & Percent & Valid Percent & $\begin{array}{c}\text { Cumulative } \\
\text { Percent }\end{array}$ \\
\hline \multirow{3}{*}{ Valid } & Sequent & 14 & 100.0 & 100.0 & 100.0 \\
\hline & Global & 0 & 0 & 0 & \\
\hline & Total & 14 & 100.0 & 100.0 & \\
\hline
\end{tabular}

Table 11 presents the distribution of learning styles of 22 knowledge worker who are working in the food production division. The participants are more visual than verbal as regards input preferences $(72.7 \%$ and $27.3 \%$ respectively); they are more active than reflective as regards the dimension of procession $(90.9 \%$ and $9.1 \%$ respectively); their style of comprehension is more sequential than global $(90.9 \%$ and $9.1 \%$ respectively); and as regards their style of perception they are more sensing than intuitive $(81.8 \%$ and $18.2 \%$ respectively). 
Paper-Massive Open Online Course Related Learning Style and Technology Usage Patterns of Thai...

Table 11. Overall distribution of the learning style dimension in the food production division.

\begin{tabular}{|c|c|c|c|c|c|}
\hline \multicolumn{6}{|c|}{ Procession } \\
\hline & & Frequenoy & Percent & Valid Percent & $\begin{array}{c}\text { Cumulative } \\
\text { Percent }\end{array}$ \\
\hline \multirow{3}{*}{ Valid } & Active & 20 & 90.9 & 90.9 & 90.9 \\
\hline & Reflective & 2 & 9.1 & 9.1 & 100.0 \\
\hline & Total & 22 & 100.0 & 100.0 & \\
\hline \multicolumn{6}{|c|}{ Perception } \\
\hline & & Frequenoy & Percent & Valid Percent & $\begin{array}{c}\text { Cumulative } \\
\text { Percent }\end{array}$ \\
\hline \multirow{3}{*}{ Valid } & Sensing & 18 & 81.8 & 81.8 & 81.8 \\
\hline & Intuitive & 4 & 18.2 & 18.2 & 100.0 \\
\hline & Total & 22 & 100.0 & 100.0 & \\
\hline \multicolumn{6}{|c|}{ Input } \\
\hline & & Frequenoy & Percent & Valid Percent & $\begin{array}{c}\text { Cumulative } \\
\text { Percent }\end{array}$ \\
\hline \multirow{3}{*}{ Valid } & Visual & 16 & 72.7 & 72.7 & 72.7 \\
\hline & Verbal & 6 & 27.3 & 27.3 & 100.0 \\
\hline & Total & 22 & 100.0 & 100.0 & \\
\hline \multicolumn{6}{|c|}{ Comprehension } \\
\hline & & Frequency & Percent & Valid Percent & $\begin{array}{c}\text { Cumulative } \\
\text { Percent }\end{array}$ \\
\hline \multirow{3}{*}{ Valid } & Sequent & 20 & 90.9 & 90.9 & 90.9 \\
\hline & Global & 2 & 9.1 & 9.1 & 100.0 \\
\hline & Total & 22 & 100.0 & 100.0 & \\
\hline
\end{tabular}

Table 12 presents the distribution of learning styles of 20 knowledge worker who are working in the travel agency division. The participants are more verbal than visual as regards input preferences ( $60 \%$ and $40 \%$ respectively); they are more active than reflective as regards the dimension of procession $(80 \%$ and $20 \%$ respectively); their style of comprehension is more sequential than global ( $90 \%$ and $10 \%$ respectively); and as regards their style of perception they are more sensing than intuitive $(90 \%$ and $10 \%$ respectively). 
Paper-Massive Open Online Course Related Learning Style and Technology Usage Patterns of Thai...

Table 12. Overall distribution of the learning style dimension for the travel agency division.

\begin{tabular}{|c|c|c|c|c|c|}
\hline \multicolumn{6}{|c|}{ Procession } \\
\hline & & Frequency & Percent & Valid Percent & $\begin{array}{c}\text { Cumulative } \\
\text { Percent }\end{array}$ \\
\hline \multirow{3}{*}{ Valid } & Active & 16 & 80.0 & 80.0 & 80.0 \\
\hline & Reflective & 4 & 20.0 & 20.0 & 100.0 \\
\hline & Total & 20 & 100.0 & 100.0 & \\
\hline \multicolumn{6}{|c|}{ Perception } \\
\hline & & Frequency & Percent & Valid Percent & $\begin{array}{c}\text { Cumulative } \\
\text { Percent }\end{array}$ \\
\hline \multirow{3}{*}{ Valid } & Sensing & 18 & 90.0 & 90.0 & 90.0 \\
\hline & Intuitive & 2 & 10.0 & 10.0 & 100.0 \\
\hline & Total & 20 & 100.0 & 100.0 & \\
\hline \multicolumn{6}{|c|}{ Input } \\
\hline & & Frequency & Percent & Valid Percent & $\begin{array}{c}\text { Cumulative } \\
\text { Percent }\end{array}$ \\
\hline \multirow{3}{*}{ Valid } & Visual & 8 & 40.0 & 40.0 & 40.0 \\
\hline & Verbal & 12 & 60.0 & 60.0 & 100.0 \\
\hline & Total & 20 & 100.0 & 100.0 & \\
\hline \multicolumn{6}{|c|}{ Comprehension } \\
\hline & & Frequency & Percent & Valid Percent & $\begin{array}{c}\text { Cumulative } \\
\text { Percent }\end{array}$ \\
\hline \multirow{3}{*}{ Valid } & Sequent & 18 & 90.0 & 90.0 & 90.0 \\
\hline & Global & 2 & 10.0 & 10.0 & 100.0 \\
\hline & Total & 20 & 100.0 & 100.0 & \\
\hline
\end{tabular}

Table 13 presents the distribution of the overall learning style of 18 knowledge worker who are working at the tour operator division. The participants are more visual than verbal as regards input preferences (55.6\% and $44.4 \%$ respectively); they are more active than reflective as regards the dimension of procession $(88.9 \%$ and $11.1 \%$ respectively); their style of comprehension is more sequential than global $(100 \%$ and $0 \%$ respectively); and as regards their style of perception they are more sensing than intuitive (100\% and $0 \%$ respectively). 
Paper-Massive Open Online Course Related Learning Style and Technology Usage Patterns of Thai...

Table 13. Overall distribution of the learning style dimension for the tour operator division.

\begin{tabular}{|c|c|c|c|c|c|}
\hline \multicolumn{6}{|c|}{ Procession } \\
\hline & & Frequency & Percent & Valid Percent & $\begin{array}{c}\text { Cumulative } \\
\text { Percent }\end{array}$ \\
\hline \multirow{3}{*}{ Valid } & Active & 16 & 88.9 & 88.9 & 88.9 \\
\hline & Reflective & 2 & 11.1 & 11.1 & 100.0 \\
\hline & Total & 18 & 100.0 & 100.0 & \\
\hline \multicolumn{6}{|c|}{ Perception } \\
\hline & & Frequency & Percent & Valid Percent & $\begin{array}{c}\text { Cumulative } \\
\text { Percent }\end{array}$ \\
\hline \multirow{3}{*}{ Valid } & Sensing & 18 & 100.0 & 100.0 & 100.0 \\
\hline & Intuitive & 0 & 0 & 0 & \\
\hline & Total & 18 & 100.0 & 100.0 & \\
\hline \multicolumn{6}{|c|}{ Input } \\
\hline & & Frequency & Percent & Valid Percent & $\begin{array}{c}\text { Cumulative } \\
\text { Percent }\end{array}$ \\
\hline \multirow{3}{*}{ Valid } & Visual & 10 & 55.6 & 55.6 & 55.6 \\
\hline & Verbal & 8 & 44.4 & 44.4 & 100.0 \\
\hline & Total & 18 & 100.0 & 100.0 & \\
\hline \multicolumn{6}{|c|}{ Comprehension } \\
\hline & & Frequency & Percent & Valid Percent & $\begin{array}{c}\text { Cumulative } \\
\text { Percent }\end{array}$ \\
\hline \multirow{3}{*}{ Valid } & Sequent & 18 & 100.0 & 100.0 & 100.0 \\
\hline & Global & 0 & 0 & 0 & \\
\hline & Total & 18 & 100.0 & 100.0 & \\
\hline
\end{tabular}

The distribution of the learning styles results of 6 knowledge workers who are working at other divisions such as information technology and human resources shows that they are more verbal as regards input preferences $(100 \%)$; they are more active as regards the dimension of procession $(100 \%)$; their style of comprehension is more sequential $(100 \%)$; and as regards their style of perception they are more sensing $(100 \%)$.

\section{Discussion and Recommendations}

The Learning Style Index model was employed in this study to identify the pattern of learning styles among knowledge workers who are working as tourism profession- 
als in five star hotels in Chiang Mai, Thailand, covering six divisions. Generally, there are four dimensions in LSI: active (acts do) and reflective (think before doing), sensing (fact) and intuitive (concept), visual (picture) and verbal (reading and explanation), sequential (learning step by step) and global (flexible learning). Overall, the distribution of the different learning styles among the observed knowledge workers who are working as tourism professionals turned out to be as follows: for $61.2 \%$ of the respondents the preferred input is visual; for $77.8 \%$ the preferred style of procession is active; for $83.4 \%$ the preferred style for comprehension is sequential; and for $88.9 \%$ of the respondents the preferred style of perception is sensing. There are not too many differences among the knowledge workers of the six different divisions as regards the preferences in learning. However, it should be noted that the verbal style as a learning input is only preferred by respondents from the housekeeping and travel agency divisions.

According to Sewall (1986) [32], there is a strong linear relationship between learners whose learning styles match the instructor's teaching styles and the students' test performances. Many studies reported that when instructors deliver learning materials based on the learning styles preferred by the learners, learning is enhanced and the course performance improves [38]. In contrast, a mismatch between the teaching style and the learning style could provide a negative effect in the academic performance among the learners. Therefore, the teaching styles of the educator must match the learning styles of the students in order to reach a better learning outcome. The researchers of this paper recommend that the course designers and instructors of the Thai ACCSTP online learning system should match their teaching style with the learners' learning style, as it will definitely result in positive impacts on the learners' performances.

Based on the findings, the researchers propose that the course designers of MOOCs should use more graphic materials in the teaching and learning process such as real models or pictures for demonstration, presentation software such as PowerPoint to attract the learner when delivering the lecture content. This should support the preferred input style. At the same time, the instructors should also promote the active learning procession style among learners by creating an integrative teaching environment. Discussion forums, brainstorming web-boards, demonstration videos, 3D simulations, cooperative learning activities, problem-based learning and project-based learning sessions in online learning are strongly recommended. On the other hand, course designers are recommended to deliver the teaching content systematically, going from easy to difficult parts in logical steps to support the learners' comprehension style. Lastly, instructors can start the lessons by emphasizing the facts followed by hands on activities to support the learners' perception of new knowledge. Moreover, giving examples or applying simulation techniques such as $3 \mathrm{D}$, visual world and storytelling enables the learners to link the learning content to real work situations allowing them a better understanding and enhanced learner performance. 


\section{Conclusion}

This study aims to identify the usage of technology devices and the patterns of learning styles of knowledge workers who are working as tourism professionals in five star hotels in Chiang Mai, Thailand, covering six divisions by employing a questionnaire set of technology usage and learning style index. For a better motivation and learning outcome of the Thai ACCSTP online learning system under the concept of MOOCs, the results regarding the usage of technology suggest that mobile technology such as the use of smartphones offers new possibilities of application since these types of devices are very commonly used by the respondents. The course designers of MOOCs are also encouraged to promote video lectures and games for educational purposes via technology devices. On the other hand, the results related to learning styles revealed that graphic materials are highly recommended as learning inputs, while the instructors need to provide an integrative teaching environment in order to promote an active style of learning procession. The courses in MOOCs should be delivered going from easy to hard lessons in logical steps to support the learners' comprehension style, followed by hands on activities to encourage learner perception.

\section{$7 \quad$ References}

[1] The Association of Southeast Asian Nations. (2013). ASEAN Overview. Retrieved 15 March 2016 from: http://www.asean.org/asean/about-asean/overview

[2] Alan Hickman and Jim Irwin, "Gap Analysis on Implementation of MRA on Tourism Professional", ASEAN-Australia Development Cooperation program, Final Report, 26 June 2013

[3] Ariffin, I., Solemon, B., Md. Din, M. dan Md. Anwar, R. (2014). Learning Style And Course Performance: An Empirical Study Of Uniten It Students. International Journal of Asian Social Science, 4(2), 208-216.

[4] Barbe, WB. and M.N. Milone, "What We Know About Modality Strengths," Educational Leadership, Feb. 1981, pp. 378-380.

[5] Cassidy, S. \& Eachus, P. (2000). Learning Styles, academic belief systems, self-report student proficiency and acdemic achievement in higher education. Educational Psychology. https://doi.org/10.1080/713663740

[6] Chula Uniserach, Preparation for Flow of Labor in the ASEAN Community,Final report, Chulalongkorn University, Retrieved 2 February 2016, from: http://www.mol.go.th/sites/ default/files/downloads/pdf/5. bththii 1 bthnam.pdf

[7] C. Parr., "MOOC Completion Rates "below 7\%", Times Higher Education. 9/May/2013

[8] Coetzee, D., Fox, A., Hearst, M. A., \& Hartmann, B. (2014). Should your MOOC forum use a reputation system?. In Proceedings of the 17th ACM conference on Computer supported cooperative work \& social computing (pp. 1176-1187). https://doi.org/10.1145/253 1602.2531657

[9] Creswell, J. W. (2013). Qualitative inquiry and research design: Choosing among five approaches (3rd ed.). Thousand Oaks, CA: Sage, pp.153.

[10] Felder, R. M. \& Silverman, L. K. (1988). Learning and teaching styles in engineering education. Journal of Engineering Education, 78(7), 674-681. 
Paper-Massive Open Online Course Related Learning Style and Technology Usage Patterns of Thai...

[11] Felder, R. M. (1996). Matter of Style. ASEE Prism, 6, 18-23. http://www4.ncsu.edu/unity/lockers/users/f/felder/public/Papers/LS-Prism.htm

[12] Felder, R. M. \& Henriques, E. R. (1995). Learning and teaching styles in foreign and second language education. Foreign Language Annals. https://doi.org/10.1111/j.19449720.1995.tb00767.x

[13] Felder, F. M. \& Soloman, B. A. (1991). Index of Learning Styles. North Carolina State University. 15 May 2009 www.ncsu.edu/effective_teaching/ILSdir/ILS-a.htm.

[14] Felder, R. \& Spurlin, J. (2005). Applications, Reliability, and Validity of the Index of Learning Styles. International Journal of Engineering Education.

[15] Graf, S., Kinshuk \& Liu, T. C.(2009) Supporting Teachers in Identifying Students' Learning Styles in Learning Management Systems: An Automatic Student Modelling Approach. Educational Technology.

[16] Graf, S., Viola, S. R., Leo, T. \& Kinshuk. (2007). In-depth analysis of the Felder- Silverman Learning Style dimensions. Journal of Research on Technology in Education. https://doi.org/10.1080/15391523.2007.10782498

[17] Graf, S., \& Kinshuk (2006). An approach for detecting learning styles in learning management systems. Proceedings of the International Conference on Advanced Learning Technologies, Los Alamitos, CA: IEEE Computer Society Press, 161-163. https://doi.org/10.1109/ICALT.2006.1652395

[18] Guo, P. J., Kim, J., \& Rubin, R. (2014). How video production affects student engagement: An empirical study of MOOC videos. In Proceedings of the first ACM conference on Learning@ scale conference (pp. 41-50). https://doi.org/10.1145/2556 325.2566239

[19] Hong, H. \& Kinshuk (2004). Adaptation to Student Learning Styles in Web Based Educational Systems. Proceedings of EDMEDIA2004, Chesapeake, VA: AACE.

[20] Kamaruddin, M. I. \& Mohamad, A. (2011). Kajian Gaya Pembelajaran Dalam Kalangan Pelajar UTM. Fakulti Pendidikan, Universiti Teknologi Malaysia, Malaysia. Journal of Educational Psychology and Counseling, 2, 51-77.

[21] Kizilcec, R. F., Piech, C., \& Schneider, E. (2013, April). Deconstructing disengagement: analyzing learner subpopulations in massive open online courses. In Proceedings of the Third International Conference on Learning Analytics and Knowledge (pp. 170-179). ACM. https://doi.org/10.1145/2460296.2460330

[22] KoIb, D.A., Experiential Learning: Experience as the Source of Learning and Development, PrenticeHall, Englewood Cliffs, N.J., 1984.

[23] Laxmisha Rai and Deng Chunrao, Influencing Factors of Success and Failure in MOOC and General Analysis of Learner Behavior, International Journal of Information and Education Technology, Vol. 6, No. 4, April 2016 https://doi.org/10.7763/IJIET.2016.V6.697

[24] Levy, P. S. \& Lemeshow, S. (2008). Sampling of populations: Methods and applications. Oxford: Wiley-Blackwell. https://doi.org/10.1002/9780470374597

[25] Litzinger, T. A., Lee, S. H. \& Wise, J. C. (2005). A Study of the Reliability and Validity of the Felder-Soloman Index of Learning Styles, Penn State University, Proceedings of the 2005 American Society for Engineering Education Annual Conference \& Exposition.

[26] M. D. Dickey, "Game Design Narrative for Learning: Appropriating Adventure Game Design Narrative Devices and Techniques for the Design of Interactive Learning Environments," Educ. Technol. Res. Dev., vol. 54, no. 3, pp. 245-263, 2006. https://doi.org/10.1007/s11423-006-8806-y

[27] Maturing of the MOOC: Literature Review of Massive Open Online Courses and other Forms of Online and Distance Learning. (September 2013). 
Paper-Massive Open Online Course Related Learning Style and Technology Usage Patterns of Thai...

[28] Ministry of tourism and Sport, Ministry of Tourism and Sport go ahead to develop the performance of Thai workers by E-learning system and get to ASEAN - MRA. 2013. Retrieved 20 March 2016: http://www.mots.go.th/

[29] Myers, 1B. And Myers, PB., Gifts Differing, Consulting Psychologists Press. Palo Alto, Calif., 1980.

[30] Oxford, R. L. (2003). Language learning styles and strategies: An overview. GALA, 1-25.

[31] Rodriguez, O. (2013). The concept of openness behind $\mathrm{c}$ and $\mathrm{x}$-MOOCs (Massive Open Online Courses). Open Praxis, 5(1), 67-73. https://doi.org/10.5944/openpraxis.5.1.42

[32] Sewall, T. J. (1986). The Measurement of Learning Style: A Critique of Four Assessment Tools. Wisconsin, USA: Wisconsin University

[33] S. Chernbumroong, P. Sureephong (2015) THE EFFECT OF COGNITIVE LOAD AND INTERACTIVE MEDIA ON KNOWLEDGE WORKERS' MOBILE LEARNING PERFORMANCE, EDULEARN15 Proceedings, pp. 5322-5330.

[34] Siemens, G. (2005). Connectivism: A learning theory for the digital age. International Journal of Instructional Technology and Distance Learning, 2(1), 3-10.

[35] Silverman, L.K., "Global Learners: Our Forgotten Gifted Children," Paper presented at the 7th World Conference on Gifted and Talented Children, Salt Lake City, Ut., Aug. 1987.

[36] T.K. Tee et al., "The Pattern of Learning Styles among Second Year Students in Business Management and Hospitality Programs at One of the Vocational College in Northern Zone", Procedia - Social and Behavioral Sciences 204 (2015) 62 - 72. https://doi.org/10.1016/j.sbspro.2015.08.110

[37] Yuan, L and Powell, S. (2013). MOOCs and Open Education: Implications for Higher Education, Available at: http://publications.cetis.ac.uk/2013/667

[38] Zywno, M. (2003). A Contribution to Validation of Score Meaning for Felder-Soloman's Index of Learning Styles. ASEE Conference. Nashville, Tennessee.

\section{Authors}

Suepphong Chernbumroong is with the Knowledge Innovation Research Laboratory (KIRLY), College of Arts, Media and Technology, Chiang Mai University, Chiang Mai, Thailand, 50200 (suepphong@kic.camt.info).

Pradorn Sureephong is with the College of Arts, Media and Technology, Chiang Mai University, Chiang Mai, Thailand, 50200.

Kitti Puritat is with the Knowledge Innovation Research Laboratory (KIRLY), College of Arts, Media and Technology, Chiang Mai University, Chiang Mai, Thailand, 50200.

Article submitted 14 June 2017. Published as resubmitted by the authors 02 August 2017. 